\title{
FitzGerald or Fitz-Omar: Ideological Reconsideration of the English Translation of Khayyam's Rubaiyat
}

\author{
Shilan Shafiei \\ English Language Department, Foreign Languages Faculty, University of Isfahan \\ PO box 81746-73441, Hezar Jarib Steet, University of Isfahan, Isfahan, Iran \\ Tel: 98-938-625-6364 E-mail: shilan.shafiei@gmail.com
}

Received: January 15, 2012

doi:10.5539/ells.v2n1p128
Accepted: January 31, 2012

Published: March 1, 2012

URL: http://dx.doi.org/10.5539/ells.v2n1p128

\begin{abstract}
The present study attempted to examine whether Edward Fitzgerald's English translation of Khayyam's Rubaiyat is effective in doing justice to the true philosophical/ideological image of Khayyam and his poems through investigating the extent of ideological manipulation applied by Fitzgerald in his translation, and through referring to the fundamental tenets of Post-colonialism.

For this purpose, the content of all the quatrains in the first edition of the translation of Rubaiyat by Fitzgerald with their corresponding Persian equivalents, were analyzed. Using the ideological manipulation theory of Zauberga as the theoretical framework, the results indicated that the form of deletion was of the highest frequency.

Finally, the key concepts of Khayyam's philosophy and his poetry, and the traces of Fitzgerald's colonialistic attitude toward Khayyam in his translation were investigated. The results revealed that the English translation of Fitzgerald has been subjected to ideological manipulations, and the translator has distorted Khayyam's true image.
\end{abstract}

Keywords: Ideology, Manipulation, Ideological manipulation, Rubaiyat, Post-Colonialism

\section{Introduction}

Whenever there is a need for communication between two nations with different languages, translation, as a medium of communication, occurs. According to Heylen (1993), a translated text is the "rewritten form of an original text" (p. 5). Every text reflects a certain ideology and poetics whereby manipulating literature to function in a given society in a certain way. The concept of manipulation in translation has inspired numerous studies in the past decades (Hermans 1985, Bassnett 1987, Bassenett \& Lefevere 1990, Venuti 1992, \& others). Most of these studies have focused on the role of manipulation in translation, how it affects the target text as a product, and what roles the manipulated target texts play in the target language community.

The literature of every nation reflects the interests, beliefs, and culture of that nation. Strictly speaking, every nation's literature and culture are inter-related. In conveying this culture, translation of its masterpieces plays a significant role. Unfortunately, in the process of translation, many formal and semantic aspects of the work evaporate through the ideological manipulation applied by the translator, even to such an extent that it can culminate in the distortion of the writer's philosophy and ideology; consequently, the true image of the writer presented to other nations is obliterated. Hence, a manipulated image of the writer, based on the translator's own ideology or the dominant ideology of his time, is introduced into the readership.

The present study is meant to examine the extent of ideological manipulation applied by Edward Fitzgerald in the translation of Khayyam's Rubaiyat to make the poems befitting the taste and demand of his readers and it will focus on the content and the semantic profundity of the original poems which have been distorted in their translations. Also, benefiting from different scholars' interpretations and analyses of Khayyam's poetry, this study investigates whether or not the Epicurean image of Khayyam created by Fitzgerald is an authentic image.

\section{Review of Related Literature and Studies}

\subsection{Manipulation \& Manipulation School of Translation}

In general, translational manipulation has not been a widely discussed topic of late, at least not by scholars writing in English. Thus the Routledge Encyclopedia of Translation Studies (1998/2001) makes no mention of manipulation at all; the Dictionary of Translation Studies (1997) contains a reference on the Manipulation School, but provides no 
definition or explanation of manipulation as a term in Translation Studies or cites no samples of manipulation in translation as such.

Scholars writing on the manipulative aspects of translation concentrate on one particular text type, usually literary texts, or on one particular type of manipulation, usually ideological manipulation or (inter)cultural manipulation. According to Ben-Ari (2000), as cited in $\operatorname{Li}$ (2005), "ideological manipulation is any interference with the text; be it cultural and ideological, religious, political or otherwise, imposed modifications that are not textual constraints, for the purpose of indoctrination".

The Manipulation School represents an approach to translation as manipulation or more precisely as rewriting of texts for a specific target audience in conformity with target language norms and under various constraints. Some of its most prominent members are James Holmes, André Lefevere, José Lambert, Theo Hermans, Susan Bassnett and, Itamar Even-Zohar, Gideon Toury.

The label 'manipulation group or school' certainly does not reflect the full spectrum of the group's views, but rather highlights one of its most provocative statements, namely, that from the target perspective "all translation implies a degree of manipulation of the source text for a certain purpose" (Hermans, 1985, p. 11). For the purposes of the current paper, this claim of Hermans will be focused.

\subsection{Ideology in Translation}

In order to make the ruling class' interests appear to be the interests of all, ideology always makes full use of special role of translation. Translation can introduce new concepts, new devices and it helps the dominant institutions legitimize the current order through values, conceptions, and symbol systems.

Álvarez and Vidal (1996), as cited in Nesvet (2005), argue:

If we are aware that translating is not merely passing from one text to another, transferring the words from one container to another, but rather transporting one entire culture to another with all that this entails, we realize just how important it is to be conscious of the ideology that underlies a translation. (p. 424)

At the most general level, "ideologies function to maintain dominance over other groups or to resist such dominance groups" (Van Dijk, 1998, as cited in Sunderlin, 2003, p. 16). At a more specific level, the ideologies of dominant groups may serve to conceal or obfuscate the truth and defend the group against criticism. The ideologies of dominated groups serve to empower them and "to create solidarity, to organize struggle and to sustain opposition" (Van Dijk, 1998, as cited in Sunderlin, 2003, p. 16).

As Lefevere (1992) states, "Translation is, of course, a rewriting of an original text. All rewritings, whatever their intention, reflect a certain ideology and a poetics and as such manipulate literature to function in a given society in a given way." That is to say, translation is determined by two basic factors: the translator's ideology and the poetics dominant in the receiving culture. Ideology dictates translation selection and translation strategies to some extent.

\subsection{Some Earlier Related Works}

In her article "Manipulation in Translation" which was an empirical study on the manipulation of text by translators, Farahzad (2007) worked on ten male and ten female English to Persian translators as her subjects. The text chosen for the study was a feministic text. The translation of the male translators of the words 'feminist' and 'feminism' showed a type of negative attitudes, while female translation of them showed positive views. Thus, their choices were ideological and caused manipulative shifts. The paper concluded that translation shifts are one type of manipulation. If a translator tries not to translate a lexical item, he manipulates the text. It is the case even in cases where the translator is not conscious of his choice.

Honey (2006) in her article worked on the translation of Nelson Mandela's autobiography, 'Long Walk to Freedom,' which played an important role in making many South Africans aware of their country's history. The study was based on a descriptive approach, specifically as manifested in the manipulation theory of André Lefevere. The various ways in which the text has been manipulated in the production of its translation, both to make it function as a text in the target language and in ways that cannot always be justified on that basis, lead to the conclusion that it is very difficult to translate autobiography without interfering with the very personal telling of a person's life story by that person, and without modulating the narration in a way that cannot always be reconciled with the autobiographer's ideology.

In his paper entitled "Translation as Manipulation: a Case Study of Yan Fu's Rendition of on Liberty", Xianbin (2005) investigated manipulation in the translation of Mill's 'On Liberty' by Yan Fu. He concluded that the translator has shifted the focus of the title, added terms and statements about social Darwinism, and supplied each paragraph with a summarizing note. His translation conveyed slight different ideas of liberty and the two texts exerted differing influence on the cultural contexts. This case study exemplified that shift of emphasis is also a kind 
of manipulation.

\subsection{Different Opinions on Fitzgerald's Translation}

One of the most striking examples of the ideological manipulation is what Edward Fitzgerald (1859) has applied in his famous so-called translation of the Persian poet Omar Khayyam's Rubaiyat. The work of the enormously popular Victorian rewriter of Khayyam, Fitzgerald, as Lefevere (1992) states,

is the most effective rewritings of the last century, and its influence makes itself felt deep into the present one. Ideologically Fitzgerald obviously thinks Persians inferior to their Victorian English counterparts, a frame of mind that allows him to rewrite them in a way in which he would have never dreamed of rewriting Homer, or Virgil. (p. 8)

In his translation of a 12th-century manuscript of The Rubaiyat, made with the help of Omar Ali-Shah, the Sufi poet and classical Persian scholar, Robert Graves claimed that Fitzgerald's version of Omar Khayyam's mystical poem has been erroneously accepted throughout the West as a drunkard's rambling profession of hedonistic creed: 'let us eat and drink for tomorrow we die'. He adds that "Edward Fitzgerald is widely celebrated as the supposed originator of the Rubaiyat, rather than as an easygoing amateur Orientalist who constructed a mid-Victorian poem of his own from an ill-understood classical Persian text" (Graves \& Ali-Shah, 1967, p. 2).

In Some side-lights upon Edward Fitzgerald's poem, The Rubaiyat of Omar Khayyam, Norton (as cited in Heron-Allen, 1898) contends that "Fitzgerald is to be called 'translator' only in default of a better word" (p. 5), one which should express the poetic transfusion of a poetic spirit from one language to another, and the re-representation of the ideas and the images of the original in a form not altogether diverse from their own, but perfectly adapted to the new conditions of time, place, custom and habit of mind in which they reappear... It is the work of a poet; not a copy, but a reproduction; not a translation, but the redelivery of a poetic inspiration.

In Fifteen Discourses, Heron-Allen (as cited in Minovi, 1988) asserts that stated in the fewest possible words, "the poem familiar to English readers as the Rubaiyat of Omar Khayyam is the expressed result of Fitzgerald entire course of Persian studies" (p. 333). There are many isolated lines and ideas, and more than one entire quatrain for which diligent study has revealed no corresponding passages in the original quatrains of Omar Khayyam.

According to Yohannan (1977, p. 102), "cutting and curtailing" is entirely approved by Fitzgerald.

\subsection{A Model for Analysis}

\subsubsection{Zauberga's Theory of Ideological Manipulation}

The ideological manipulation theory of Zauberga (2004) is the main theoretical framework applied by the researcher of the present study to answer the first research question.

According to Zauberga (2004), ideological manipulation can take the following forms:

- Deletion (Omissions): used to be a frequently pursued translation strategy due to political and moral considerations.

- Substitution: made both on ideological and moral grounds.

- $\quad$ Addition

- Attenuation (Softening): another widely used strategy applied due to moral considerations to mitigate taboo words or "upgrade" substandard language.

\subsubsection{Basic Concepts in Post-colonialism}

Post-colonialism is often referred to as 'third-world literature' by Marxist critics - a term many other critics think pejorative. "Post-colonial literature and theory investigate what happens when two cultures clash and when one of them, with its accompanying ideology, empowers and deems itself superior to the other" (Bressler, 2007, p. 237).

The most prominent figure who contributed a lot to the growth of the Post-colonial studies was Edward Said, a Palestinian-American literary theorist, cultural critic and political activist. Said (1978), in Orientalism, claimed a subtle and persistent Eurocentric prejudice against Arabo-Islamic peoples and their culture. He has defined his understanding of cultural practice of Orientalism as a western style for dominating, restructuring, and having authority over the Orient. He has asserted that Orientalism is a discourse system that cannot be understood apart from recognizing it as the enormously systematic discipline by which European culture was able to manage and even produce the Orient politically, sociologically, military, ideologically, scientifically, and imaginatively during the post-enlightenment and Victorian period.

According to More-Gilbert (1997), Post-colonial studies use a concept called 'Otherness' a somewhat flexible concept deriving from Freudian psychiatry, which argues that human beings inevitably define themselves against 
what they are not - the 'other'.

\section{Purpose and Research Questions}

Regarding what Fitzgerald as the translator of Rubaiyat says, "better a live sparrow than a stuffed Eagle" (Yohannan, 1977, p. 103), one finds it vital to investigate what Fitzgerald actually did as a translator and whether we can call him a translator who intended to make Khayyam known to the world or a poet who exploited our poet's artistic skills as a launch pad to his own success and popularity.

This study seeks to answer the following questions:

1. According to the ideological manipulation theory of Zauberga (2004), what is the extent of ideological manipulation applied by Fitzgerald in his translation of Khayyam's Rubaiyat?

2. Is Fitzgerald's translation effective in doing justice to the true philosophical/ ideological image of Khayyam and his poems and does it unfold any traces of colonialism according to the fundamental tenets of Post-colonialism?

\section{Methodology}

\subsection{Materials}

In this study, Rubaiyat of Omar Khayyam by Khorramshahi (1994), rendered into English verse by Edward Fitzgerald (First and Fifth edition) with original Persian text edited by Foroughi, has been chosen. This book includes a collection of 178 Persian quatrains that Foroughi and Ghani have selected among a myriad of quatrains attributed to Khayyam, along with 75 English translated quatrains in the first edition and 101 in the fifth edition. For the purposes of the present study, the English verses of the first edition would be analyzed and compared with the corresponding Persian Rubaiyat. It has been found out that these 178 Persian and 75 English quatrains have about 32 quatrains in common, i.e. 32 Persian verses with their corresponding 32 English ones. Therefore, to find the rest of the Persian quatrains with their corresponding equivalents, the present study selected another source, The Rubaiyat of Omar Khayyam Explained by Yogananda (1994), containing all 75 quatrains from the first edition of Fitzgerald's translation with their corresponding Persian ones.

\subsection{Procedures}

To answer the first research question, the first edition of Fitzgerald's translation containing 75 quatrains was compared, according to the ideological manipulation of Zauberga (2004), with Khayyam's Rubaiyat to quantify the frequency of the cases of deletion, addition, substitution and attenuation (if any), which occurred in the process of translating the above-mentioned quatrains from Persian into English by Fitzgerald. A qualitative approach was adopted to answer the second question. First, the reasons for the widespread popularity of Fitzgerald's rendition and its influence were investigated; second, through benefitting from some interpretations of Khayyam's poems made by current Iranian and foreign literary scholars and through pointing to his use of religious treasures, the study attempted to unveil his true image; Finally, according to the fundamental tenets of Post-colonialism, the traces of Fitzgerald's colonial attitude in rendering Khayyam's Rubaiyat were discussed.

\section{Results and Discussion}

\subsection{Cases of Ideological Manipulation in FitzGerald's Translation}

To determine the cases of deletion, addition, substitution and attenuation which were discussed in Section 2.5, 2 (out of a total of 75) Persian quatrains are written in front of their corresponding English translation and then the above mentioned cases are written under them.

Quatrain 1

Awake! for Morning in the Bowl of Night [xoršid] [kcemcende] [sobh] [bor] [bam] [cefkcend]

Has flung the Stone that puts the Stars to Flight: $\quad$ [keyxosroe] [ruz], [badeh] [dcer] [jam] [aefkend]

And Lo! the Hunter of the East has caught [mey] [xor] [ke] [monadi] [scehorgceh] [xizan]

The Sultan's Turret in a Noose of Light. [ [avazeh] [cešrcebu] [doer] [ceyam] [aefkcend].

Addition: all four lines in English

Deletion: all four lines in Farsi

Deletion: [æšræbu]

Quatrain 2 
I heard a Voice within the Tavern cry,

"Awake, my Little ones, and fill the Cup

Before Life's Liquor in its Cup be dry."

Substitution: [meyxaneh]: tavern

Substitution: [mey]: liquor

Substitution: [rende] [xærabati] [o] [divanehe] [ma]: my little ones

Substitution: [peymaneh] (in the $4^{\text {th }}$ line): cup (in the $4^{\text {th }}$ line)

Substitution: [por]: dry

Deletion: the $1^{\text {st }}$ line in English

\subsubsection{Frequency of the Cases of Ideological Manipulation}

The following charts and diagrams shows the results obtained through enumerating the ideological manipulation cases according to Zauberga's theory of Ideological manipulation.

Table 1 illustrates the number of the three cases of ideological manipulation forms detected in each English quatrain. It is worth mentioning that no cases of the forth form of manipulation, attenuation, have been found in the quatrains. 105, 92 and 60 cases for the three forms, deletion, substitution and addition respectively, were realized for all 75 quatrains.

Figure 1 displays the contribution of each form of ideological manipulation to the total in percentage in the English translation of Rubaiyat. Deletion, with the highest frequency, allocates forty one percent of all forms of manipulation to itself. Substitution and addition with thirty six and twenty three percent respectively present the other two forms.

Figure 2 depicts the number of addition cases each of the quatrains in the English translation of Rubaiyat are subject to. Among the 75 quatrains, no. 29 has the highest number of addition cases, i.e. 3 ones.

Figure 3 illustrates the number of deletion cases which have been detected in the English translated quatrains. As it is shown, the quatrain no. 40 is of the maximum number of these cases, i.e. 4 cases.

Figure 4 displays the number of substitution cases found in the quatrains of Fitzgerald's translation. The quatrain no. 2 , as shown in the figure, has the highest number of the cases of this manipulation form, i.e. 5 cases.

Figure 5 shows the sum of the number of all three manipulation forms in each English translated quatrain. Quatrains no. 24 and no. 70 have the highest and the lowest total number of these cases respectively, i.e. 7 and 1 cases.

\subsubsection{Analysis of Some Quatrains in Detail}

Quatrain 1 in section 5.1

As it is observed, there is no general correspondence between the source lines and the translated lines. In other words, the images that are created in the reader's mind through reading the four Persian lines are completely distinct from those created through reading the four English lines. Not only the concrete words ([xoršid], [badeh], [ĵam], [kæmænd] ...) but also the message of the original quatrain, inviting the man to drink the wine (of love for God) everyday with the sunrise, have been manipulated. Khayyam's bringing the word '[æšræbu]', an Arabic word seemingly extracted from the verses of Quran, which may not be unintentional provides evidence for the figurative sense of the wine with a religious load.

Quatrain 2 in section 5.1

The word '[meyxaneh]' has a more cultural and figurative load than its English equivalent in this quatrain: 'tavern' which is "an establishment where alcoholic beverages are sold to be drunk on the premises" (Merriam-Webster Online Dictionary, 2009). In Persian poetry, '[meyxaneh]' is the inside of a perfect mystic (Fallah, 2008). The word '[mey]' has been translated to 'liquor' that has a less literary load. In addition, through translating '[mey]', a mystical concept in Persian poetry, to 'liquor', an exclusively concrete noun, its meaning has been narrowed down to just "a strong alcoholic drink" (Merriam-Webster Online Dictionary, 2009). The culture-bound word '[rend]' in the expression '[rende] [xærabati] [o] [divanehe] [ma]' has been simply substituted with the neutral expression 'my little ones'. The image created in the reader's mind through reading the forth line in Persian is different from the one created in English.

\subsection{Khayyam's Image through Fitzgerald's Rubaiyat}

5.2.1 The Fame of Fitzgerald's Rubaiyat: Where does it come from?

It was Fitzgerald that for the first time introduced Khayyam to the world of literature; his everlasting translation is 
being praised by his readership, particularly the literary figures, throughout the world. As Mason \& Mason (2007) in The Art of Omar Khayyam state, when Fitzgerald published his version of Rubaiyat of Omar Khayyam in the Victorian era in 1859; he could have had no idea of the 'Omar' publishing industry that would evolve from his action. In fact this was the beginning of a unique publishing phenomenon. Over the century and a half since that date, there has been a continual flow of subsequent publications of Omar Khayyam's Rubaiyat.

Pound (1922), as cited in Yohannan (1977), could say that "Fitzgerald's translation of Omar is the only good poem of the Victorian era that has got beyond a fame de cenacle" (p. 245).

Yohannan (1977) asserts that Fitzgerald's fame was enhanced in 1885 due to the fact that Tennyson dedicated his Tiresias to FitzGerald's memory, in some touching reminiscent verses to 'Old Fitz'. This was but the signal for that universal appreciation of Omar Khayyam in his English version. He adds that Rubaiyat became better known to the general public than any single poem of the time. The following lines are what Tennyson, as cited in Yohannan (1977), says about Fitzgerald' translation:

"Fitzgerald's...golden Eastern lay

Then which I know no version done

In English more divinely well;

A planet equal to the sun

Which cast it, that large infidel

Your Omar; and your Omar drew

Full-handed plaudits from our best" (p. 94)...

Edward Fitzgerald is widely celebrated as the supposed originator of the Rubaiyat, a collection that its publication in 1858 coincided with a strong anti-devotional movement among young English ex-Protestants encouraged in their revolt by Charles Darwin's newly broached doctrine of Evolution (Graves \& Ali Shah, 1967).

Bloom (2004) believes that the consensus to explain the Rubaiyat success is that the times were ripe for works repudiating the traditional religious morality and attempting to find an alternative to it. Another reason he adds is that it is indeed startling to realize that the date of the Rubaiyat first appearance, 1859, coincides with that of Darwin's Origin of Species. Judging by its later popularity, Fitzgerald caught the mood of the times. Partly this was to do with a gloomy awareness of humanity's newly discovered condition as an evolved ape living on an insignificant speck of rock in the middle of nowhere.

\subsubsection{What did Rubaiyat Fame in West Result in?}

According to Granger (2009), the common view in the West of the Rubaiyat of Omar Khayyam is that it is a collection of sensual love poems.

The Rubaiyat is famous for, Hitchens (2007) holds, its warm recommendations of wine, women and song. Thus, the poet counsels us to eat, drink and be merry, enjoying the simple pleasures of life and making the most of the time that we have. The poem is strikingly unorthodox in its tone, dissenting from the established Islam of the poet's day and scorning the ideas of an afterlife or a god who performs miracles or gives revelations.

Khayyam is credited with a flat denial either that has an ultimate sense or purpose, or that the Creator can be, in justice, allowed any of the mercy, wisdom or perfection illogically attributed to Him (Graves \& Ali Shah, 1967).

In the recent years some parts of Khayyam's poetry have been abused under the influence of Fitzgerald's famous translation; specially the following line that has been written under an ignominious caricature of Khayyam and his lover in Playboy, an American men's magazine:

"A Jug of Wine, a loaf of Bread, Are free but 'thou' is going to cost you, Omar"

Apart from the label 'hedonist' that Fitzgerald's translation planted in the mind of his readership, as Graves \& Ali-Shah (1967) believe, "Fitzgerald seems to have been the first writer either in the West or East to present Khayyam as a blasphemer" (p. 37).

\subsection{The Other Side of the Coin: Khayyam's Image through His Rubaiyat}

It may be said that there are few people like Khayyam who have been engaged in different paradoxical poles of conflicts, some believe that he is an atheist, and some believe that he is a pious man, a group of people became his follower because of bringing the words like beloved, wine, etc. in his poetry, and the last group believe that he is a skeptical philosopher that looks at the whole world with doubt, and claim that his attempt to perceive the universe has ended in nothingness. 
Khayyam's thoughts and reflections have been cloaked in his words, although they seem very simple. We can say that some of the conflicts are the result of Khayyam's poetry which is somehow a multi-faceted one; at the same time he speaks about life, death, existence, glory, and other important things.

The aim of the present section is first to briefly interpret some of Khayyam's poems using different scholars' opinions to show the delicacy and mystical load of his poetry, and second to indicate the fact that Khayyam is a Muslim poet and philosopher and like other Persian Muslim poets, has profoundly benefited from Quran and Hadith in his poems.

5.3.1 Interpretation of Khayyam's Rubaiyat

Quatrain 1

[bor] [xiz] [bota] [biar] [bcehre] [dele] [ma]

[hoel] [kon] [be] [ĵcemale] [xiš] [moškele] [ma]

[yek] [kuzeh] [šcerab] [ta] [be] [hoem] [nušs] [konim]

[zan] [piš] [ke] [kuzeha] [koncend] [cez] [gele] [ma]

According to Yogananda (1994), "wine ([šærab], [mey]) is the wine of mercy from God" (p. 22). In the same line, Monsieur Nicolas, French Consul at Rasht, who had published a literal translation of Rubaiyat into French, pointed out that saki ([saqi]) means 'God' and wine ([šærab]) means 'love' in Khayyam's Rubaiyat. He considered Omar "a Mystic, shadowing the Deity under the figure of Wine, Wine-bearer and was indeed using Wine and Beauty as images to illustrate the Divinity he was celebrating" (cited in Graves \& Ali-Shah, 1967, p. 18).

It is worth mentioning that in some versions, the following quatrain which is closer to its English translation has been mentioned:

[amced] [scehceri] [neda] [ze] [meyxanehe] [ma]

[ke] [ey] [rende] [xcerabati] [o] [divanehe] [ma]

[barxiz] [ke] [por] [konim] [peymaneh] [ze] [mey]

[zan] [piš] [ke] [por] [koncend] [peymanehe] [ma]

Cry ([neda]) stands for the cry of soul and the purity of body, tavern ([meyxanehe]) is the silent inner sanctum of human being, wine ([mey]) is the happiness of life, and finally cup ([peymanehe]) is body of soul (p. 22).

According to Graves \& Ali-Shah (1967, p. 4), "Khayyam treats wine as a metaphor of the ecstasy by divine love: a simple concept not really grasped by Westerns."

In this regard, Dashti (1966) maintains that there are so many quatrains that talk about 'wine' and the benefits of it, but most of them are not Khayyam's quatrains. It's believed that drinking wine is a sign of superiority for some people. It may be true, but not for a man like Khayyam who knows art, religion, philosophy, and wisdom better than anybody else.

Quatrain 2

[vaeqte] [scehor] [cest] [xiz] [ey] [mayehe] [naz]

[ncermoek] [ncermoek] [badeh] [xor] [o] [čceng] [ncevaz]

[kanha] [ke] [bejaycend] [ncepaycend] [boesi]

[voe] [anha] [ke] [šodcend] [kces] [nemiayced] [baz]

Walters, as cited in Yogananda (1994), states that like other great scholars Khayyam recommends people to live in the moment and not to waste their energy with thinking about the past or future. The past has been vanished forever and the future is still in ambiguity. Another example of Khayyam's Rubaiyat in this regard is:

[čun] [bolbole] [moest] [rahe] [bostan] [yaft]

[ruye] [gol] [o] [jam] [badeh] [ra] [xcendan] [yaft]

[amced] [be] [zcebane] [hal] [dcer] [gušcem] [goft]

[dceryab] [ke] [omre] [roefte] [ra] [ncetvan] [yaft]

"If you are happy in the moment, you will perceive God. Are these thoughts always in conformity with revelry and debauch?" (p. 30).

5.3.2 Rubaiyat, Holy Quran and Hadith

"Khayyam's use of Quran and Hadith includes the application of concepts, words and Qur'anic messages" (Quran 
and Hadith in Khayyam's Poetry, 2008, p. 11). Some of the related examples extracted from the above-mentioned article are as follows.

Example 1:

[cez] [dey] [gozcešt] [hič] [cez] [u] [yad] [mcekon]

[fcerda] [ke] [nceyamcedcest] [fceryad] [mcekon]

[bcer] [namcedeh] [o] [gozcešteh] [bonyad] [mcekon]

[hali] [xoš] [baš] [o] [omr] [bcer] [bad] [mcekon]

Allusion to the following verse of Quran is obvious:

[lekceyla] [tce?su] [cela] [ma] [fatekom]. (celhcedid: 23)

"In order to that ye may not despair over matters that pass you by, nor exult over favors bestowed upon you. For Allah loveth not any vainglorious boaster" (Ali, 1938, p. 1504).

Also Imam Ali (A.S.) in a poem says:

[mafatce] [mceza] [vee] [mce?seatikce] [fce?ceyn]

[qom] [fce?ceqteneme] [celforscetce] [bceynce] [celcedcemceyn]

One that is passed is over and one that comes is where?

Rise and benefit from the time between two no-wheres? (Ahlul Bayt DILP team, 2008).

In addition to the above quatrain, there are other quatrains that have the same allusion to Quran such as following one:

[ey] [del] [qceme] [in] [jochane] [forsudeh] [moexor]

[bihudeh] [nei] [qoemane] [bihudeh] [moexor]

[čun] [bud] [o] [gozcešt] [o] [nist] [nabudeh] [pcedid]

[xošs [baš] [o] [qceme] [budeh] [o] [nabudeh] [moexor]

Example 2:

Another example of the application of Qur'anic concepts found in Khayyam's Rubaiyat is:

[guycend] [behešt] [o] [hure] [ceyn] [xahced] [bud]

[vanja] [meye] [nab] [o] [cengaebin] [xahced] [bud]

[gar] [ma] [mey] [o] [moešuqeh] [gozidim] [če] [bak]

[axer] [nce] [be] [aqebcet] [homin] [xahoed] [bud]

The corresponding verses are:

[vce] [kcevaeb] [cetraba] (celncebce: 33)

"Companions of equal age" (p. 1676),

[vce] [kce?scen] [dehaqa] (celncebce: 34)

"And a cup full (to the brim)" (p. 1676)

And other verses like:

[voe] [huron] [ceyn] (aelvaqea: 22)

And (there will be) Companions with beautiful, big, and lustrous eyes (p. 1486),

[kce] [cemsale] [lo?loe] [celmceknun] (celvaqex: 23)

"Like unto Pearls well-guarded" (p. 1486).

Therefore, Khayyam does not find anything better than beautiful Qur'anic descriptions to describe Eden and more beautiful than Eden to describe the best states.

5.4 Fitzgerald's Colonialistic Attitude toward Khayyam's Rubaiyat

As Munday (2001) believes, "the linking of colonialization and translation is accompanied by the argument that translation has played an active role in the colonization process and in disseminating an ideologically-motivated image of colonized people" (p. 134). 
This section focuses on the way translation into English has generally been used by the colonial power to construct a rewritten image of the 'East' that has then come to stand for the truth. Specifically speaking, in this part, first, some examples of Fitzgerald's assertions about the Persians and his translation are presented; then, the tenets of Post-colonialism movement, discussed in the second section, which are applicable to his opinions are introduced.

\subsubsection{Fitzgerald's Claims}

- $\quad$ As Bassnet \& Trivedi (1999) report, "Edward Fitzgerald wrote a letter to Cowell (20 March 1851) and accused Persians of artistic incompetence and suggested that their poetry became art only when translated into English" (p. 130).

- Somewhere else Fitzgerald (as cited in Yohannan, 1977) states that: "It is something to get out of the sweetmeat, childish, oriental world back to the vigorous North" (p. 102).

- Fitzgerald rearranged the quatrains so as to create a unity of theme that Persian readers do not expect from what, to them, is a collection of individual poems. He described his work as "the most ingeniously tessellated into a sort of Epicurean Eclogue in a Persian Garden" (p.102).

- In a defense of his translation, "Fitzgerald explained that his second edition gave Omar's thought room to turn in. He begins with Dawn pretty sober and completive; then as he thinks and drinks, grows savage, blasphemous etc., and then again sobers down into melancholy at nightfall" (p. 103).

- What Fitzgerald wrote in one of his letters to Tennyson is notable: "I keep on reading foolish Persian, chiefly because of its connecting me with the Cowells, now besieged in Calcutta" (p. 94).

- $\quad$ Fitzgerald considered himself sufficient of a Persian expert to dismiss the poet Jalaludin Rumi, fourteenth century author of Mathnavi, with a typical insularism: "I don't speak of Jalal, whom I know so little of, but enough to show me he is no great Artist" (Graves \& Ali-Shah, 1967, p. 33).

\subsubsection{Discussion}

The afore-mentioned claims are directly related to the notion existing in Post-colonialism that investigates what happens when 'third world literature' is translated into a target language whose culture with its accompanying ideology empowers and deems itself superior to the culture of the source language. There is a constellation of false assumptions underlying the attitude of Fitzgerald, as an English man of letters, toward the East, specifically the Persians. It is clearly observed in his judgments on Khayyam.

FitzGerald's British arrogance, his belief of his inherent English superiority allowed him to think that his very limited knowledge of Persian discussed in the second section would suffice for his translation project. A member of what translation theorists label the hegemonic language and culture, FitzGerald assumes a paternalistic pose as the civilizer or improver of the dominated language and culture, Khayyam's Persian. In this interpretation, translation becomes FitzGerald's means towards an Orientalist end.

\subsection{Discussion of the Results in Detail}

In the first part of the study, the cases of ideological manipulation in Fitzgerald's translation of Khayyam's Rubaiyat were presented. The obtained results of comparing Persian version of Rubaiyat with its English translation indicated that there were 60 cases of addition, $23 \%, 105$ cases of deletion, $41 \%$ and 92 cases of substitution, $36 \%$. As it is observed, the highest degree of ideological manipulation exercised by Fitzgerald occurred in the form of deletion, the forms of substitution and addition were respectively exercised to lesser degrees. It is worth mentioning that no cases of the attenuation form were detected in the translation. Considering the explanation of this form in section two, it can be inferred that there were no offensive words in the source text to be attenuated by the translator. Moreover, the high percentage of the three other forms showed that Fitzgerald has taken liberty with the text and has manipulated it ideologically, that is, apart from considering the faithfulness to the content of the source text, he adopted it since he thought that was better for his readership.

In the second part of the study, it was shown how different the image created by Fitzgerald's translation was from the real image of Khayyam; in other words, his translation was not effective in doing justice to the true philosophical/ideological image of Khayyam. The image of a hedonist atheist is never the real image of Khayyam, a thoughtful Muslim. According to Aminrazavi (2006), Khayyam is a Muslim philosopher who is operating well within the Islamic religious universe; he is involved in the questions like 'Thereness' or what can be called 'existence'/ 'being'.

Fitzgerald's colonialistic attitude toward Orientals and especially Persian literature is out of question. He created an image that according to what was mentioned in the second section was compatible to the taste of the $19^{\text {th }}$ century Victorian people; the traces of the afore-mentioned attitude support this claim, traces that were affirmed by different 
literary scholars in this section.

\section{Conclusion}

The translator's handling of a text which results in the adaptation of the text for the target audience is manipulation. It considers the cultural, ideological, linguistic and literary differences between the cultures in contact and takes place within a particular cultural setting and carried out by a human agent, with consequence of a possible influence of individual- or psychology-related factors upon the end product.

Assuming the statement by Hermans (1985) that suggests, "from the point of view of the target literature all translation implies a degree of manipulation of the source text for a certain purpose" (p. 11), one may ask this question that 'to what extent can manipulation occur in the text?' Considering the role of translation as a connecting bridge among nations on the one hand and the issue of manipulation on the other, which has a negative side when it comes to the translation studies, the translator, particularly the translator of the literary texts, should pay a specific attention to the question of manipulation and its ideological form which can have a close relation to the true image of the writer, poet and the text itself. Therefore, it is incumbent on the translator to have an eye on the author of the source text and his/her nationality apart from any prejudice against him/her.

Regarding the indisputably notable role of the translator, as the manipulator of the text, in depicting a probably false image of the original writer/poet to the world through his/her (mostly ideology-induced) manipulation, the present study sought to draw the attention of the translators to this fact that their opinions and experiences do influence their achievement and they may make them choose certain translatorial strategies or words or styles of writing that perhaps are not exactly right for the text.

Based on the results of the quantitative and qualitative analyses of the Rubaiyat rendition by Fitzgerald made in the present study, it was proved that Fitzgerald has translated Rubaiyat with a prejudice stemming from his individual preferences and ideology, the dominant atmosphere of his time and a colonial attitude toward Persians.

In the quantitative part, it was shown that he has manipulated the source text according to his own preferences, in most cases for the sake of poetry aesthetics; and sometimes without any reason he has changed the words, changes that could have been done without deleting, adding or substituting a special concept or word. Anyway, such manipulation, consciously or unconsciously, has distorted the main issues of Khayyam's poetry and has changed the whole work into a kind of splendidly-performed wordplay.

In the qualitative part, the evidences given by the researcher and the supporting proofs presented in section two on Victorian period revealed that Fitzgerald has manipulated Khayyam's image to conform it to his own taste, and to quench his peers' and contemporaries' thirsty for praising worldly matters and forgetting all about the strict rules of society. Unfortunately, the effects of such a distorted image still prevail in the West.

\section{References}

Ali, A. Y. (1938). The Holy Quran, Text, Translation \& Commentary. Lahore: Kashmiri Bazar. pp. 1486-1676

Aminrazavi, M. (2006). Martin Heidegger and Omar Khayyam on the Question of "Thereness" (Dasein). In A. T. Tymieniecka (Ed.), Islamic Philosophy and Occidental Phenomenology on the Perennial Issue of Microcosm and Macrocosm (pp. 277-287). Netherlands: Springer. http://dx.doi.org/10.1007/978-1-4020-4115-0_19

Bassnet, S., \& Trivedi, H. (1999). Post-Colonial Translation. Great Britain: Clays Ltd, St Ives plc. p. 130

Bloom, H. (2004). Edward Fitzgerald's The Rubaiyat of Omar Khayyam. Philadelphia: Chelsea House Publishers.

Bressler, C. E. (2007). Literary Criticism: An Introduction to Theory and Practice. New Jersey: Pearson Education, Inc., Upper Saddle River. p. 237

Dashti, A. (1966). A while with Khayyam. Tehran: Asatir Pubication.

Fallah, R. (2008). Sign and Symbol. [Online] Available: http://www.magiran.com/npview.asp?ID=1655166. (2009)

Farahzad, F. (2007). Manipulation in Translation. [Online] Available: http://www.shvoong.com/humanities/linguistics/1726979-manipulation-translation/ (2009)

Fitzgerald, E. (1859). Rubaiyat of Omar Khayyam. London: George C. Harrap.

Granger, I. M. (2009). Omar Khayyam. Poetry Chaikhana, Sacred Poetry from Around the World. [Online] Available: http://www.poetry-chaikhana.com/blog/2009/04/. (2009)

Graves, R., \& Ali-Shah, O. (1967). The Rubaiyyat of Omar Khayaam. London: Cassell \& Company LTD. p. 2-37

Hermans, T. (1985). Introduction: Translation Studies and New Paradigm. In T. H. (Ed.), (1985). In The Manipulation of Literature: Studies in Literary Translation (p. 11). London and Sydney: Croom Helm. 
Heron-Allen, E. (1898). Some Side-Lights upon Edward Fitzgerald's Poem the Rubaiyat of Omar Khayyam. London: H. S. Nichols Ltd. p. 5

Heylen, R. (1993). Translation, Poetics and the Stage: Six French Hamlets. London: Routledge. p. 5

Hitchens, C. (2007). Poetry Sunday: The Rubaiyat of Omar Khayyam. [Online] Available: Daylight Atheism: http://www.daylightatheism.org/2008/11/poetry-sunday-xix.html (2012)

Honey, M. F. (2006, March). (Un)(sub)conscious manipulation: Antjie Krog's translation of Nelson Mandela's 'Long walk to freedom'. [Online] Available: SUNScholar: http://scholar.sun.ac.za/handle/10019.1/2183 (2012)

Khorramshahi, B. (1994). Rubaiyat of Omar Khayyam. Tehran: Nahid Publication.

Lefevere, A. (1992). Translation, Rewriting and the Manipulation of Literary Fame. London and New York: Routledge. p. 8

Li, L. (2005, April). Ideological Manipulation in Translation in a Chinese Context: Su Manshu's Translation of Les Misérables. [Online] Available: Translation Journal: http://translationjournal.net/journal/32ideology.htm (2012)

Liquor. (2009). In Merriam-Webster Online Dictionary. [Online] Available: http://www.merriam-webster.com/dictionary/liquor (2009)

Mason, W., \& Mason, S. (2007). Art of Omar Khayyam: Illustrating Fitzgerald's Rubaiyat. London: I. B. Tauris \& Company, Limited.

Minovi, M. (1988). Fifteen Discourses. Tehran: Toos Publication. p. 333

More-Gilbert, B. (1997). Postcolonial Theory: Contexts, Practices, Politics. New York: Verso.

Munday, J. (2001). Introducing Translation Studies. London: Routledge. p. 134

Nesvet, R. (2005, June). Parallel Histories: Dryden's Plutarch and Religious Toleration. The Review of English Studies, New Series, 56(225), p. 424. http://dx.doi.org/10.1093/res/hgi059

Quran and Hadith in Khayyam's Poetry. (2008, May 12). Etedal Daily, p. 11.

Said, E. W. (1978). Orientalism. New York: Vintage Books.

Sunderlin, W. D. (2003). Ideology, Social Theory, and the Environment. Lanham, Md.: Rowman \& Littlefield. p. 16

Tavern. (2009). In Merriam-Webster Online Dictionary. [Online] Available: http://www.merriam-webster.com/dictionary/tavern (2009)

Xianbin, H. (2005). Translation as Manipulation: a Case Study of yan fu's Rendition of on Liberty. [Online] Available: Translatum: http://www.translatum.gr/journal/5/yan-fu-on-liberty.htm (2009)

Yohannan, J. D. (1977). Persian Poetry in English and America. New York: Caravan Book. pp. 94-245

Yogananda, P. (1994). The Rubaiyat of Omar Khayyam Explained. California: Crystal Clarity Publishers. pp. 22-30

Zauberga, I. (2004). Theoretical Tools for Professional Translators. Rīga: N.I.M.S. 
Table 1. No. of Cases Detected for Ideological Manipulation Forms (addition, deletion, substitution) in the English Version of Khayyam's Rubaiyat

\begin{tabular}{|c|c|c|c|c|c|c|c|}
\hline \multirow{2}{*}{$\begin{array}{c}\text { No. of } \\
\text { Quatrain }\end{array}$} & \multicolumn{3}{|c|}{ Ideological Manipulation Forms } & \multirow{2}{*}{$\begin{array}{l}\text { No. of } \\
\text { Quatrain }\end{array}$} & \multicolumn{3}{|c|}{ Ideological Manipulation Forms } \\
\hline & Addition & Deletion & Substitution & & Addition & Deletion & Substitution \\
\hline 1 & 1 & 2 & 0 & 38 & 2 & 3 & 0 \\
\hline 2 & 0 & 1 & 5 & 39 & 1 & 2 & 2 \\
\hline 3 & 1 & 1 & 0 & 40 & 1 & 4 & 1 \\
\hline 4 & 1 & 1 & 0 & 41 & 1 & 0 & 2 \\
\hline 5 & 1 & 2 & 1 & 42 & 0 & 3 & 3 \\
\hline 6 & 1 & 1 & 0 & 43 & 2 & 2 & 2 \\
\hline 7 & 2 & 3 & 1 & 44 & 1 & 3 & 0 \\
\hline 8 & 1 & 2 & 0 & 45 & 1 & 2 & 1 \\
\hline 9 & 2 & 1 & 0 & 46 & 0 & 1 & 1 \\
\hline 10 & 1 & 2 & 0 & 47 & 0 & 0 & 3 \\
\hline 11 & 0 & 0 & 4 & 48 & 1 & 1 & 2 \\
\hline 12 & 0 & 1 & 2 & 49 & 0 & 2 & 2 \\
\hline 13 & 0 & 0 & 2 & 50 & 0 & 2 & 1 \\
\hline 14 & 1 & 1 & 0 & 51 & 0 & 3 & 1 \\
\hline 15 & 1 & 2 & 0 & 52 & 1 & 2 & 0 \\
\hline 16 & 0 & 2 & 1 & 53 & 1 & 2 & 0 \\
\hline 17 & 1 & 0 & 2 & 54 & 1 & 2 & 1 \\
\hline 18 & 1 & 1 & 3 & 55 & 1 & 1 & 0 \\
\hline 19 & 0 & 1 & 2 & 56 & 0 & 2 & 3 \\
\hline 20 & 1 & 0 & 1 & 57 & 0 & 1 & 2 \\
\hline 21 & 1 & 1 & 3 & 58 & 1 & 1 & 1 \\
\hline 22 & 1 & 2 & 1 & 59 & 1 & 3 & 0 \\
\hline 23 & 1 & 1 & 1 & 60 & 1 & 1 & 0 \\
\hline 24 & 2 & 3 & 2 & 61 & 1 & 1 & 0 \\
\hline 25 & 1 & 1 & 2 & 62 & 0 & 0 & 2 \\
\hline 26 & 1 & 2 & 1 & 63 & 1 & 1 & 1 \\
\hline 27 & 1 & 2 & 0 & 64 & 1 & 2 & 0 \\
\hline 28 & 0 & 0 & 2 & 65 & 1 & 0 & 2 \\
\hline 29 & 3 & 1 & 0 & 66 & 1 & 3 & 0 \\
\hline 30 & 0 & 2 & 3 & 67 & 1 & 1 & 1 \\
\hline 31 & 1 & 0 & 4 & 68 & 0 & 1 & 2 \\
\hline 32 & 1 & 1 & 1 & 69 & 1 & 3 & 2 \\
\hline 33 & 1 & 1 & 1 & 70 & 0 & 0 & 1 \\
\hline 34 & 0 & 1 & 2 & 71 & 0 & 1 & 2 \\
\hline 35 & 1 & 1 & 0 & 72 & 0 & 1 & 1 \\
\hline 36 & 1 & 1 & 1 & 73 & 1 & 0 & 1 \\
\hline \multirow[t]{2}{*}{37} & 1 & 1 & 1 & 74 & 1 & 2 & 0 \\
\hline & & & & 75 & 1 & 2 & 0 \\
\hline
\end{tabular}




\begin{tabular}{|l|l|l|l|l|l|l|l|}
\hline & & & & Total & 60 & 105 & 92 \\
\hline & & & & Total (\%) & 23 & 41 & 36 \\
\hline
\end{tabular}

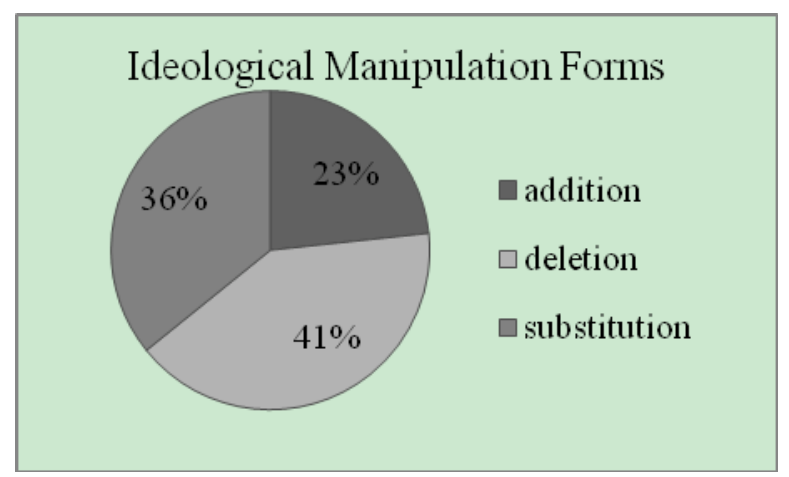

Figure 1. The Pie Chart Displaying the Contribution of Each Form of Ideological Manipulation to the Total in the English Version of Khayyam's Rubaiyat

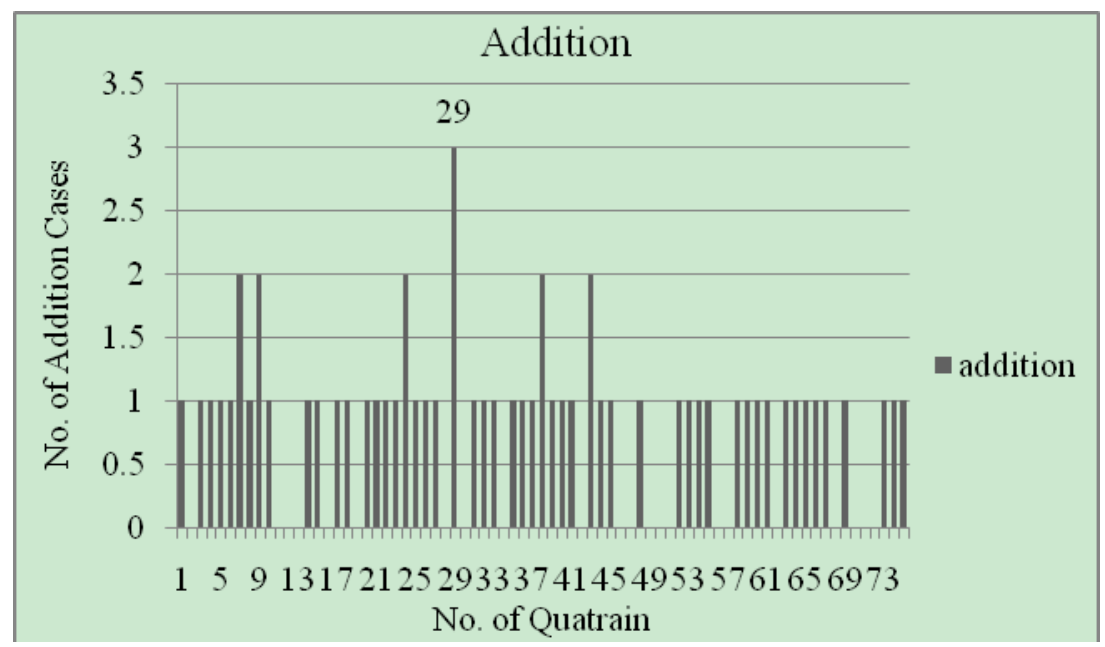

Figure 2. The Column Chart Displaying No. of Addition Cases Detected in the English Version of Khayyam's Rubaiyat

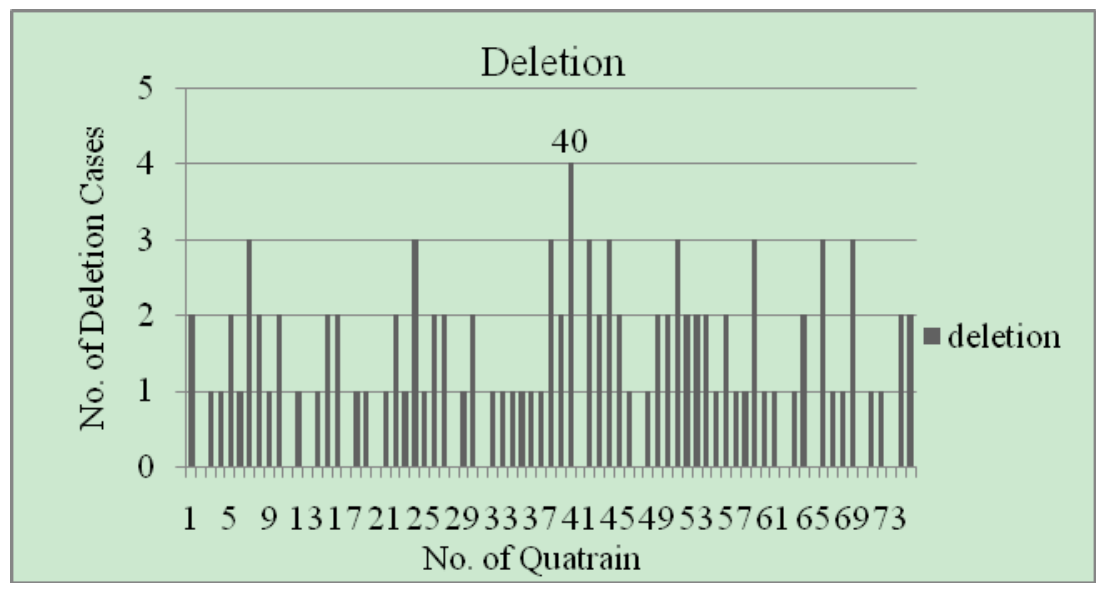

Figure 3. The Column Chart Displaying No. of Deletion Cases Detected in the English Version of Khayyam's Rubaiyat 


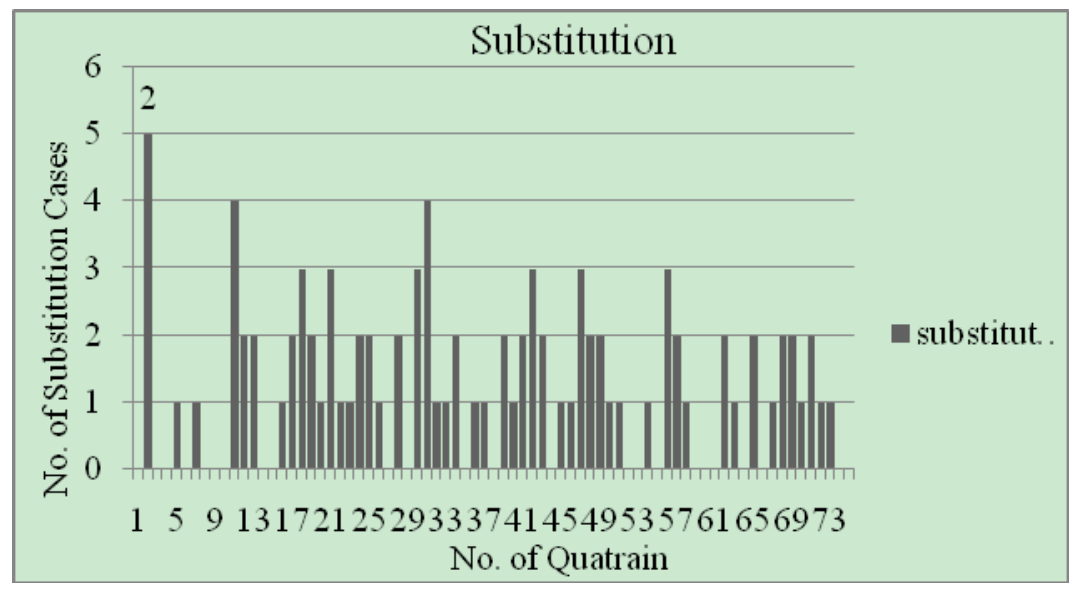

Figure 4. The Column Chart Displaying No. of Substitution Cases Detected in the English Version of Khayyam's Rubaiyat

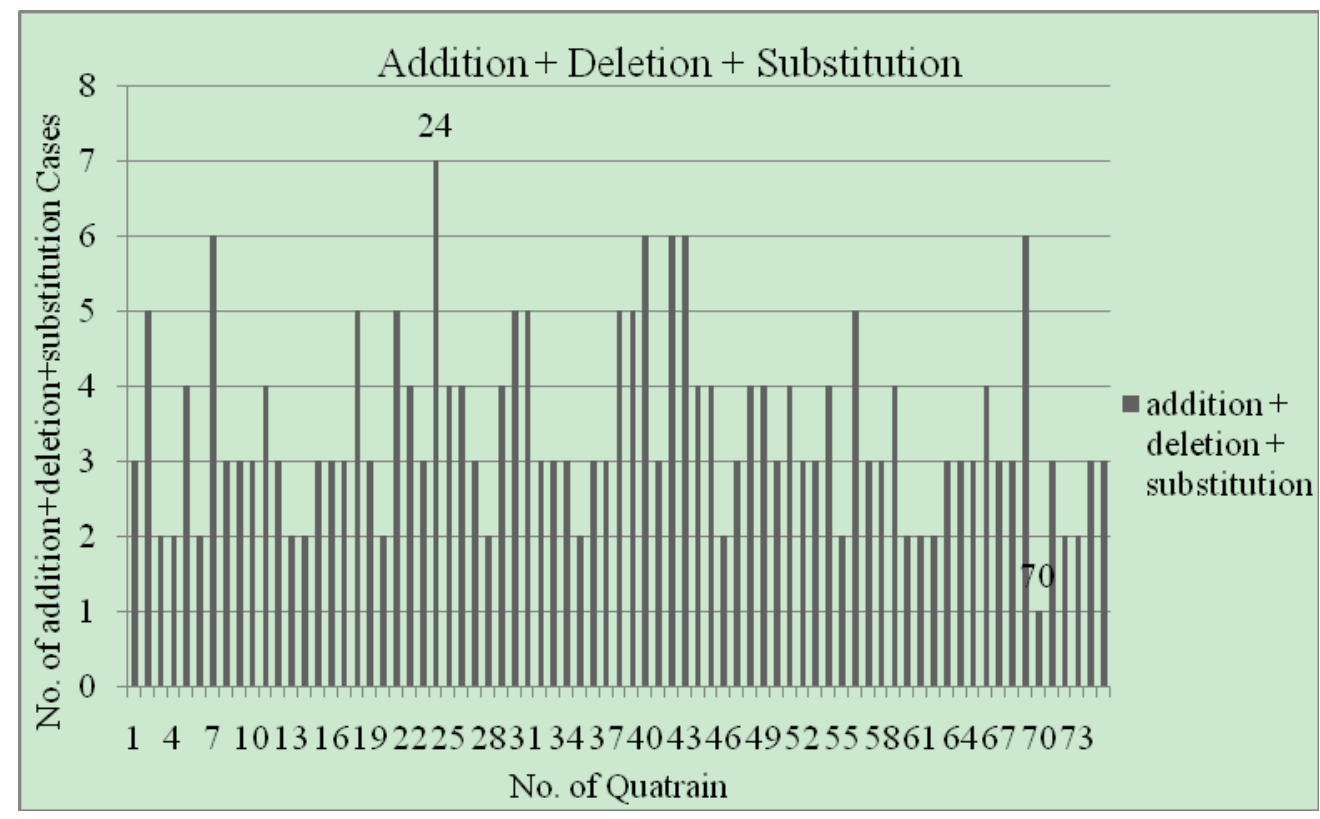

Figure 5. The Column Chart Displaying No. of Addition + Deletion + Substitution Cases Detected in the English Version of Khayyam's Rubaiyat 